\title{
Solar Based Automatic Grass Cutting Robot.
}

Prof. V. K. Thombare

Assist. Prof. Dept.of Electrical Engg.

Ashokrao Mane Group of

Institution

Kolhapur, India 416112

chavanvinaya19@gmail.com
Ashish Kadam

UG, Dept.of Electrical Engg.

Ashokrao Mane Group of

Institution

Kolhapur, India 416112

kadamashish1998@gmail.com

Vaibhav Kaingade

UG, Dept.of Electrical Engg.

Ashokrao Mane Group of

Institution

Kolhapur, India 416112

vaibhavkaingade00@gmail.com
Ranjit Pawar

UG, Dept.of Electrical Engg.

Ashokrao Mane Group of

Institution

Kolhapur, India 416112

ranjitpawar5333@gmail.com

\begin{abstract}
This paper focuses towards working of automatic solar grass cutter. Automatic solar grass cutter reduces the effort requiredfor cutting grass in the lawns. Also, solar power will be used to provide the driving force for the cutter and the various sensors will be used to detect and avoid the unnecessary objects in the field during operations. This system also operate on a battery that will also be charged through solar energy rather than using any external power. In this ultrasonic sensors are also used to detect any object/human/oranimal while cutting the grass so to avoid them. It consists of microcontroller Arduino ATMEGA328U, LCD display for better response and understanding to the user. This paper will project the operation and working principle of the automatic grass cutter. Also, the design parameters are discussed in this paper.
\end{abstract}

\section{INTRODUCTION}

Intelligent robots are vision, all intelligent robots work precisely, using multiple degree of coordinate motion and does something like a human, they mimic expected human response, they learn from humans making mistakes. Over the years there have been numerous developments in grass cutter technology. Nowadays pollution is a major concern in all parts of the environment. In order to make our environment attractive we are polluting it by gas powered and fuel based lawn mowers. By using the programmed grass cutter user can cut the grass of required area by giving input. The main objective of this grass cutter is that grass in lawn must be trimmed with less effort. The sensors are the eyes of this grass cutter. The other objective is that the automatic grass cutter has to distinguish between grass and concrete while monitoring its surroundings continuously. We had used an ultrasonic sensor to detect if the grass cutter was heading towards an object. And also automatically changes its direction if any obstacle or particle is in the moving path. The information about the surrounding will be given by the ultrasonic sensor to robot. We had also used accelerometer sensor in order to stop the cutter motor when the robot will be tilted at a particular angle. In order to make the robot to operatemanually the Bluetooth module is used. A solar panel is a set of solar photovoltaic modules electrically connected and mounted on a supporting structure. A photovoltaic element is a packaged, connected assembly of solar cells.

The solar panel can be used as a component of a larger photovoltaic system to generate and supply electricity in commercial and residential applications. In our project a $10 \mathrm{~W}$ Solar panel whose dimensions are $31 * 35 \mathrm{~cm}$ is used. Sun is not available for twenty hours, so it is necessary to store some energy. A fabrication or the body part material used in this project is also of less weight as a result the weight of the robot is being reduced as compared to the other available robot in market. The material used is a wooden sheet which is light in weight and also very cost efficient as compared other sheet metals The main object of this solar power grass cutter is using renewable energy source instead of fuel based energy sources. Using the solar based energy sources is easier to use, and more advantageous as comparing other energy sources. To make life easier and decreasing the need of man power. Reduce the pollution in the environment. By considering four to five papers related to the solar grass cutter project we have made various changes in order to reduce the overall defect which was occurred by the project developed by the other members. Also the main motive of our project was to work on only renewable energy resources and also to make the solar grass cutter robo very cost effective. While designing the hardware model many consideration have been done in this project such as to make the robo as possible as light in weight so it may be easy to handle for this reason instead of using a metallic sheet as a base material a wooden sheet of a better quality is used as base material as a result the fifty percent of total weight is reduced there. Also while using the wheel regular plastic or fiber wheel are used so it may be easy to move from one place to another and also the weight would become lower. This selection of all the components and all the materials is done on the basis of the old project so the new prototype which we are going to design would be of approximately less errors. Forour understanding less us consider one example of selection of battery. While considering the battery there were many options but we went with the lithium iron Phosphate ( $\mathrm{LiFePo} 4)$ Battery which was quite costly as compared with other batteries but the operational features where excellent. The efficiency and the life span of the battery are very great as compared to other batteries. 


\section{LITERATURE SURVEY}

The robot is controlled by the microprocessor Arduino AT mega328. Here the ultrasonic sensor is used to avoid the obstacles to avoid the interruptions of the robot. The motor driver also used here to interface the microprocessor and the wheel motor [4]. They have used a Bluetooth module to make the robo operate manually; because due to any circumstances the grass is being left to cut then human can easily operate with help of Bluetooth module [3]. They have used micro controllerboard of design is Arduino Uno, which is open source platformused for building the electronic projects. They conclude that, the robot is used to reduce pollution due to gas and petrol engine, it reduces risk for user solar grass cutter has a major disadvantage that is of tilting the robo as a result there is risk to damage the human body because the cutter will be visible upwards. To limit this Accelerometer sensor being used [6]. When the robo will tilt the cutter motor will automatically stop to interface the wheel motors and Arduino AT mega 328 microcontrollers with help of Motor driver. Lead acid battery of $12 \mathrm{v}$ can be used to save the power developed from the Polycrystalline based solar panel by using the handle or frame which is depend on the size of the lawnmower. [2] They are also using a bearing which is machine part, which support a moving element and confines its motion. DC motors are used for movement of wheels[7] The force which is required to cutthe grass force is require for moving should be greater than 10newtons. Precise torque and speed control without sophisticated electronics

\section{CIRCUIT CONFIGURATION}

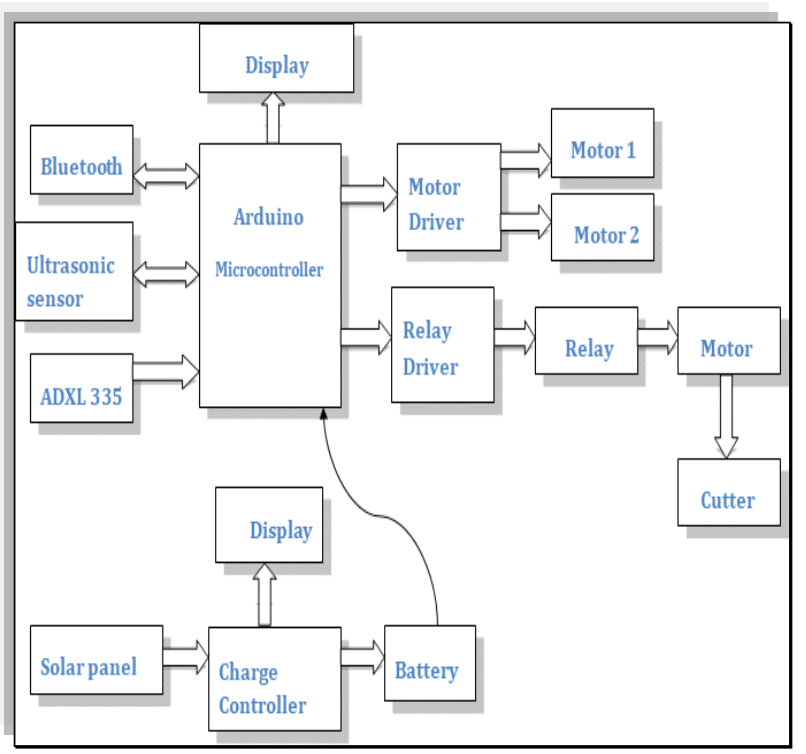

Fig 1-Block diagram of solar grass cutter

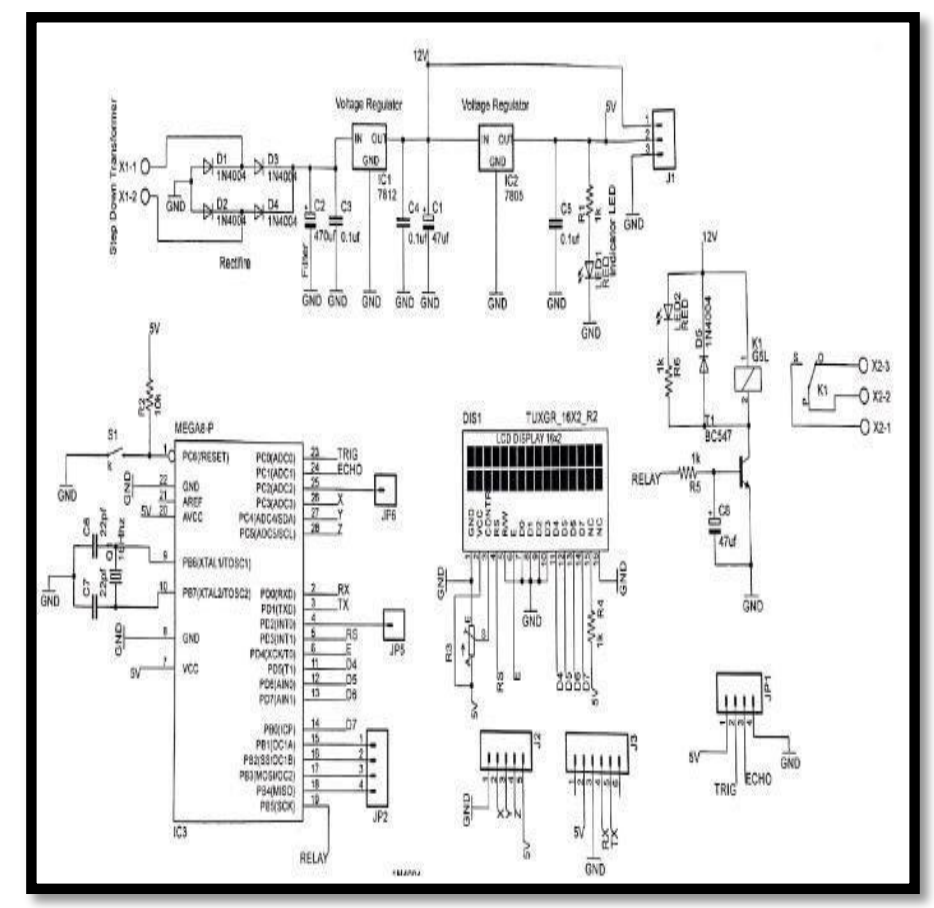

Fig 2- Circuit diagram of solar grass cutter

The design contains a microcontroller, multiple sensors, and a solar charging system. Adding these elements together, we get our robotic lawn mower. The sensors are the eyes of our Robot Initially, we had an idea what type of sensors we wanted to use. We used only an ultrasonic sensor to detect if the robot was heading into an object. Safety is the main concern when designing a robot with blades. We wanted our robot not to start operating if it was being held in the air by the user. Knowing that the user would be randomly holding the robot we needed a sensor to detect orientation. The power the system there are many options. With recharging batteries, there are various chemistries but we decided to go with the one that work best with solar charging. The Lead-Acid Battery was found to be the best because given a low charging current, it will not overcharge. Sizing the battery will depend on what we are powering, specifically the motors. Like batteries, there is a range of motors to choose from. We went with two $12 \mathrm{~V}$ DC motors with integrated gear heads. The needed torque did not need to be a lot because we were going to have a small prototype. The block diagram of automatic solar grass cutter design is shown in figure 1. Also here we have used a Accelerometer Sensor for protection of human hazardous. If by chance the robot is being tilt with some circumstances the motor of wheels and cutter motor are being automatically stopped. Here the display is being connected to indicate the 
directions of motor weather the motor is forward, reverse, right, left or stop and also the distance of robot to an obstacles. Here the motor driver is being connected between the Arduinomicrocontroller and two wheel motors to give the rated supply of motor and to operate the motor in required direction. To make the robot working manually the Bluetooth module is used here. Command is given with the help of the Android application named as Arduino Bluetooth, As per our Bluetooth instruction given to Arduino the motor direction can be controlled.

\section{SIMULATION}

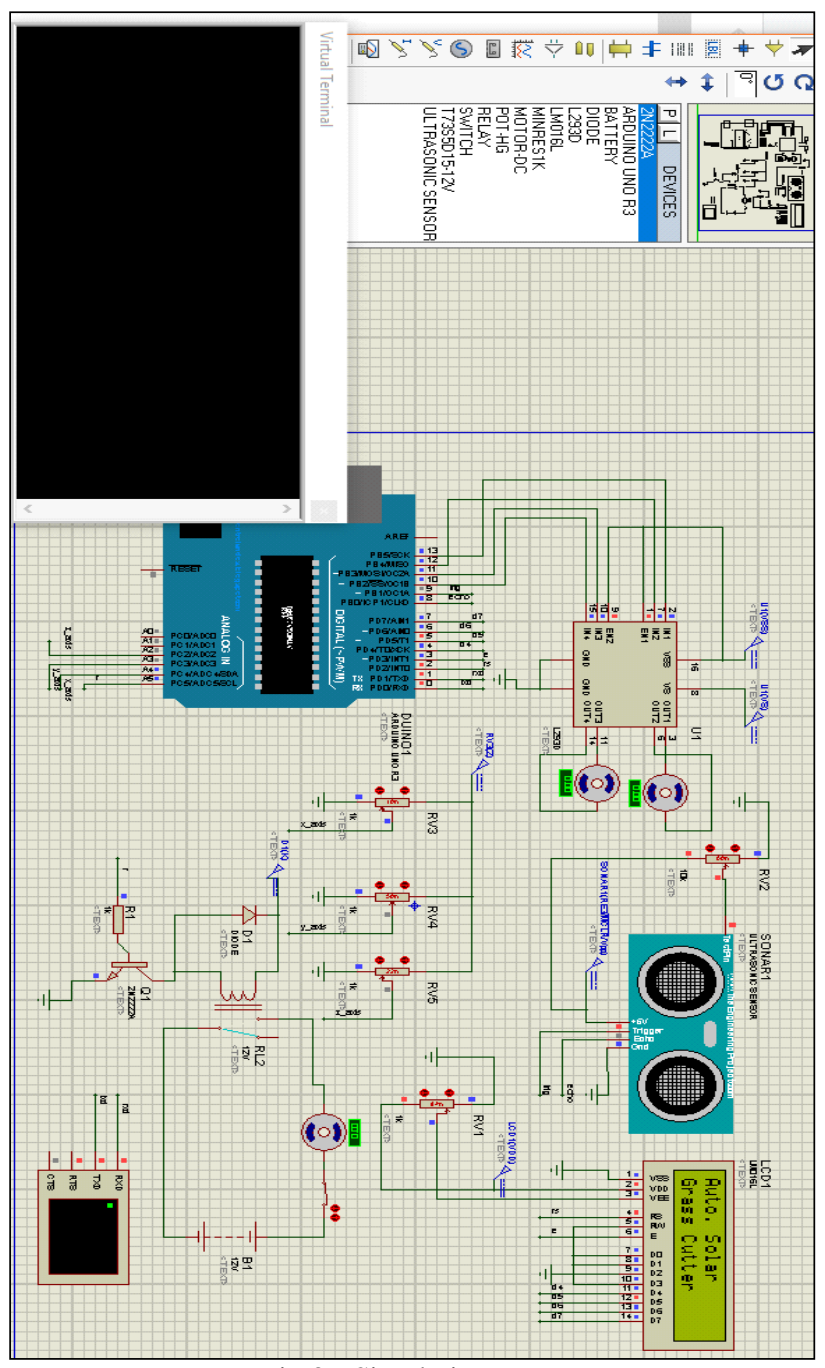

Fig 3 - Simulation

\section{CIRCUIT DETAILS}

Arduino ATMeg328 is used as a microcontroller in the circuit. There are total 28 pins out of which 13 are digital pins, 6 Analog pins, 1 RESET pin and 1 is the reference pin. Analog
Pins can also use as digital pins. Motor is interfaced to the Arduino microcontroller through the motor driver L293D.

3. Pin no 10,11,12,13 are digital pin of Arduino these pins are used to connect the motor driver and the driver circuit is connected to pin 16 and 8 for constant $5 \mathrm{~V}$ and $12 \mathrm{~V}$ supply.

4. Pin no 3, 5, 11, 14 are output pins of motor driver and are connected to $12 \mathrm{~V}, 400 \mathrm{~mA}$ and $100 \mathrm{RPM}$ rating of motor 1 and motor 2 respectively.

Data lines of LCD D4, D5, D6, and D7 are connected to control lines of LCD. RS and E are connected to controller pins 2 and 3.constant $5 \mathrm{~V}$ supply is applied to the $\mathrm{Vcc}$ terminal of LCD .Pin TxD and RxD are the digital pins of the Arduino and are connected to pin RxD and TxD of Virtual Instrument respectively. Virtual instrument is used as a Bluetooth module. Data can be transmitted through TxD pin of Arduino is received by RxD pin of Virtual Instrument and vice versa.

Trigger and echo are the pins of the ultrasonic sensor are connect to the pin no 7 and 8 of controller.Trigger pin is act as transmitter and echo pin is act as a receiver. constant $5 \mathrm{~V}$ supply is applied to the Vcc terminal of ultrasonic sensor.A3, A4, A5 are the analog pins of the controller are connect to the $\mathrm{x}$-axis, $\mathrm{y}$-axis and $\mathrm{z}$ Axis of accelerometer sensor. Here the potentiometer is used to vary the distance of $\mathrm{z}$ axis.A6 is the analog pin of the controller is connecting to the base terminal of the transistor and emitter terminal are grounded. Constant $12 \mathrm{~V}$ supply is applied to the relay through collector terminal of transistor. Here the diode is used because coil is inductive in nature as a result back emf is produced due to change in polarity hence to operate continuous diode is used. The relay used here SPDT (single pole double throw).secondary terminal of relay is connected to the $12 \mathrm{~V}, 1 \mathrm{Amp}$ rating DC motor.

\section{RESULT}

From the above all hardware models we got result as follows:

\section{MANUAL MODE:}

A. If we press following keys in the Arduino control Android Application which is connected to the HC-05 Bluetooth module we will get following results:

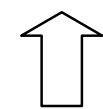

(Upward arrow) key = motor will move forward.

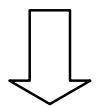

(Downward arrow) key=motor will move reverse 
Table: 2 PCB Relay

(Left arrow) key=motor will turn left.

(Square Sign) key=motor will stop.

B. By doing the changes in Arduino program we can give delay for motor to run and stop. And also we can change the distance of the ultrasonic sensor and also of the accelerometer sensor. We can also change the Battery and solar Panel rating by replacing with higher rating battery and solar panel to increase the Storage of battery and working time of project.

\section{AUTOMATIC MODE:}

To make the robo to work Automatic you have to follow following Simple steps. Press Switch ON - Put Selector Switch to Automatic mode - Automatic mode activated. Immediately the Robot starts operating and starts the cutting process. If there is any obstacle in front of the Robot the ultrasonic sensors senses the obstacle and change the direction towards right side. This process continues until a human doesn't switch off the Robot supply. Our project entitled "solar powered autonomous grass cutting robot" is a renewable energy source base project which is overcome problems of fuel based grass cutters .It will be easier for the people who are going to take the project for the further modifications. This project is more suitable for a common man as it is having much more advantages i.e. no fuel cost, no pollution and no fuel residue, less wear and tear because of less number of moving components and this can be operated by using solar energy. This will give much less physical exertion to the people. The completed final design of solar powered autonomous grass cutting robot using proteus, Eagle, arduino and software according to calculations and simulation designed hardware of robot.

\section{DATASHEET}

Table.1 Motor Driver

\begin{tabular}{|c|c|c|c|}
\hline $\begin{array}{l}\text { DATASHEET } \\
\text { Table.1 Motor } \\
\text { Driver }\end{array}$ & & & \\
\hline & Min & Max & Unit \\
\hline Supply voltage $\mathrm{V}_{\mathrm{cc} 1}$ & & 36 & $\mathrm{~V}$ \\
\hline Output supply voltage $\mathrm{V}_{\mathrm{cc} 2}$ & & 36 & $\mathrm{~V}$ \\
\hline Input voltage $\mathrm{V} i$ & & 7 & V \\
\hline Output voltage Vo & -3 & $\begin{array}{l}\mathrm{V}_{\mathrm{cc} 2} \\
+3 \\
\end{array}$ & $\mathrm{~V}$ \\
\hline $\begin{array}{l}\text { Peak output current, Io(no repetitive, } \\
t \leq 5 \mathrm{~ms}) \text { :L293 }\end{array}$ & -2 & 2 & A \\
\hline $\begin{array}{l}\text { Peak output current, Io (no repetitive, } \\
t \leq 100 \mu \mathrm{s} \text { ):L293D }\end{array}$ & -1.2 & 1.2 & A \\
\hline Continuous output current, Io:L293 & -1 & 1 & $\mathrm{~A}$ \\
\hline Continuous output current, Io:L293D & $-\overline{6}$ & 600 & $\mathrm{~mA}$ \\
\hline Maximum junction temperature, $T_{j}$ & & 150 & ${ }^{\circ} \mathrm{C}$ \\
\hline Storage temperature, $\mathrm{T}_{\mathrm{stg}}$ & -65 & 150 & ${ }^{\circ} \mathrm{C}$ \\
\hline
\end{tabular}

\begin{tabular}{|c|c|c|c|c|c|c|c|c|}
\hline \multicolumn{2}{|c|}{ Rated voltage } & $\begin{array}{c}3 \\
\text { VD } \\
C\end{array}$ & $\begin{array}{c}5 \\
\mathrm{~V} \\
\mathrm{DC}\end{array}$ & $\begin{array}{c}6 \\
\mathrm{~V} \\
\mathrm{DC}\end{array}$ & $\begin{array}{c}9 \\
\mathrm{~V} \\
\mathrm{DC}\end{array}$ & $\begin{array}{c}12 \\
\mathrm{~V} \\
\mathrm{DC}\end{array}$ & $\begin{array}{c}24 \\
\text { VD } \\
C\end{array}$ & $\begin{array}{c}48 \\
\mathrm{~V} \\
\mathrm{DC}\end{array}$ \\
\hline \multicolumn{2}{|c|}{ Rated current } & $\begin{array}{c}166 \\
.7 \\
\mathrm{~mA}\end{array}$ & $\begin{array}{c}10 \\
0 \\
\mathrm{~m} \\
\mathrm{~A}\end{array}$ & $\begin{array}{c}83 . \\
3 \\
\mathrm{~m} \\
\mathrm{~A}\end{array}$ & $\begin{array}{c}55 . \\
6 \\
\mathrm{~m} \\
\mathrm{~A}\end{array}$ & $\begin{array}{c}41 . \\
7 \\
\mathrm{~m} \\
\mathrm{~A}\end{array}$ & $\begin{array}{c}20.8 \\
\mathrm{~mA}\end{array}$ & $\begin{array}{l}12 \\
\mathrm{~m} \\
\mathrm{~A}\end{array}$ \\
\hline \multicolumn{2}{|c|}{ Coil resistance } & $\begin{array}{l}18 \\
\Omega\end{array}$ & $\begin{array}{l}50 \\
\Omega\end{array}$ & $\begin{array}{l}72 \\
\Omega\end{array}$ & $\begin{array}{l}16 \\
2 \\
\Omega \\
\end{array}$ & $\begin{array}{c}28 \\
8 \\
\Omega \\
\end{array}$ & $\begin{array}{l}115 \\
2 \Omega\end{array}$ & $\begin{array}{c}40 \\
00 \\
\Omega \\
\end{array}$ \\
\hline \multirow{2}{*}{$\begin{array}{c}\text { Coil } \\
\text { inducta } \\
\text { nce } \\
(\mathrm{H}) \\
\text { (ref. } \\
\text { value) } \\
\end{array}$} & $\begin{array}{c}\text { Armat } \\
\text { ure } \\
\text { OFF }\end{array}$ & $\begin{array}{c}0.0 \\
4\end{array}$ & $\begin{array}{c}0.0 \\
9\end{array}$ & $\begin{array}{c}0.1 \\
6\end{array}$ & $\begin{array}{c}0.3 \\
1\end{array}$ & $\begin{array}{c}0.4 \\
7\end{array}$ & 1.98 & $\begin{array}{c}7.2 \\
3\end{array}$ \\
\hline & $\begin{array}{c}\text { Armat } \\
\text { ure } \\
\text { ON } \\
\end{array}$ & $\begin{array}{c}0.0 \\
5\end{array}$ & $\begin{array}{c}0.1 \\
1\end{array}$ & $\begin{array}{c}0.1 \\
9\end{array}$ & $\begin{array}{c}0.4 \\
9\end{array}$ & $\begin{array}{c}0.7 \\
4\end{array}$ & 2.36 & 10 \\
\hline \multicolumn{2}{|c|}{$\begin{array}{c}\text { Must operate } \\
\text { voltage }\end{array}$} & \multicolumn{7}{|c|}{$75 \%$ max. of rated voltage } \\
\hline \multicolumn{2}{|c|}{$\begin{array}{c}\text { Must release } \\
\text { voltage }\end{array}$} & \multicolumn{7}{|c|}{$5 \%$ min of rated voltage } \\
\hline \multicolumn{2}{|c|}{ Max. voltage } & \multicolumn{7}{|c|}{$120 \%$ of rated voltage at $23^{\circ} \mathrm{C}$} \\
\hline \multicolumn{2}{|c|}{$\begin{array}{c}\text { Power } \\
\text { Consumption }\end{array}$} & \multicolumn{7}{|c|}{ Approx. $500 \mathrm{~mW}$} \\
\hline
\end{tabular}


Table.3: Accelerometer

\begin{tabular}{|c|c|c|c|c|c|}
\hline Parameter & Conditions & Min & Typ & $\operatorname{Max}$ & Unit \\
\hline $\begin{array}{l}\text { SENSOR INPUT } \\
\text { Measurement } \\
\text { range } \\
\text { Non linearity } \\
\text { Package alignment } \\
\text { Error } \\
\text { Interix's } \\
\text { Alignment Error } \\
\text { Cross-axis } \\
\text { Sensitivity }\end{array}$ & $\begin{array}{l}\text { Each axis } \\
\% \text { full } \\
\text { scale }\end{array}$ & \pm 3 & $\begin{array}{l} \pm 3.6 \\
\pm 0.3 \\
\pm 1 \\
\pm 0.1 \\
\pm 1\end{array}$ & & $\begin{array}{l}\mathrm{g} \\
\% \\
\text { Degrees } \\
\text { Degrees } \\
\%\end{array}$ \\
\hline $\begin{array}{l}\text { SENSITIVITY } \\
\text { (RATIOMATRIC) } \\
\text { Sensitivity at } \\
\text { Sensitivity change }\end{array}$ & $\begin{array}{l}\text { Each axis } \\
V_{\mathrm{s}}=3 \mathrm{~V} \\
\mathrm{~V}_{\mathrm{s}}=3 \mathrm{~V}\end{array}$ & 270 & $\begin{array}{l}300 \\
\pm 0.01\end{array}$ & 330 & $\begin{array}{l}\mathrm{mV} / \mathrm{g} \\
\% /{ }^{\circ} \mathrm{C}\end{array}$ \\
\hline $\begin{array}{l}\text { ZERO g BIAS } \\
\text { LEVEL } \\
\text { (RATIOMATRIC) } \\
\text { Og Voltage at X, } \\
\mathrm{Y} \\
\text { Og Voltage at Z } \\
0 \mathrm{~g} \text { Offset vs. } \\
\text { Temperature }\end{array}$ & $\begin{array}{l}\mathrm{V}_{\mathrm{s}}=3 \mathrm{~V} \\
\mathrm{~V}_{\mathrm{s}}=3 \mathrm{~V}\end{array}$ & $\begin{array}{l}1.35 \\
1.2\end{array}$ & $\begin{array}{l}1.5 \\
1.5 \\
\pm 1\end{array}$ & $\begin{array}{l}1.65 \\
1.8\end{array}$ & $\begin{array}{l}\mathrm{V} \\
\mathrm{V} \\
\mathrm{mg} /{ }^{\circ} \mathrm{C}\end{array}$ \\
\hline $\begin{array}{l}\text { NOISE } \\
\text { PERFORMANCE } \\
\text { Noise Density X, } \\
\text { Y } \\
\text { Noise Density Z }\end{array}$ & & & $\begin{array}{l}150 \\
300\end{array}$ & & $\begin{array}{l}\mu \mathrm{g} / \sqrt{ } \mathrm{HZ} \\
\mathrm{rms} \\
\mu \mathrm{g} / \sqrt{ } \mathrm{HZ} \\
\mathrm{rms}\end{array}$ \\
\hline $\begin{array}{l}\text { FREQUENCY } \\
\text { RESPONSE } \\
\text { Bandwidth X, Y } \\
\text { Bandwidth Z } \\
\text { RFLT Tolerance } \\
\text { Sensor Resonant } \\
\text { Frequency } \\
\end{array}$ & $\begin{array}{l}\text { No } \\
\text { external } \\
\text { Filter } \\
\text { No } \\
\text { external } \\
\text { Filter } \\
\end{array}$ & & $\begin{array}{l}1600 \\
550 \\
32 \pm 15 \% \\
5.5\end{array}$ & & $\begin{array}{l}\mathrm{Hz} \\
\mathrm{Hz} \\
\mathrm{k} \square \\
\mathrm{kHz}\end{array}$ \\
\hline
\end{tabular}

\section{CONCLUSION}

This system used components are of low cost and in bulk production and adding of few more sensors doesn't makes any difference. By using this system, we can preserve the non renewable sources of energy such as petrol, gasoline etc. We can also decrease a choice of forms of pollutions such as air pollution and noise pollution. Electricity is saved as we utilize solar energy that is renewable source of energy. The simulation which is designed using protuse is almost clear the concept of robot and this is very helpful for designing hardware of solar powered autonomous grass cutting robot. Many types of sensors can be added to the Robo in order to make the Robo extremely easy to use. The size of solar panel and battery can be increased as per our requirements to increasing the operating time at a greater extent .Battery can also be externally charged from a $230 \mathrm{~V} \mathrm{AC}$ socket only by designing the rectification circuit.

\section{REFERENCES}

1. "Design and Implementation of Automatic Solar Grass Cutter".Bidgar Pravin Dilip1, Nikhil Bapu Pagar2Vickey S. Ugale3, Sandip Wani4, Prof. Sharmila M.5 UGStudent, Department of Electrical Engineering, Sandip Institute of Engineering and Management,Nashik,India1,2,3,

2. "Automated Mower Robo". Mr. Shinde Vaibhav
Tanaji1, Mr. Chavan Swaroop Chandrakant2, Mr.Parulekar Sharvarish Shashikant3, Mr. Gavali Omkar Raju4, Mr. Gokhale Shantanu Bhalchandra5 1,2,3,4,5 Department ofMechanical Engineering, KIT's College of Engineering, Kolhapur, Maharashtra, India

3. "Solar Grass Cutter Robot with Obstacle Avoidance":April2017 International journals for engineering science and computing (IJESC).

4. "Design and fabrication of remote controlled lawn mower" Varsha D1, Vasavi Suresh2, Prasad Hegde3, Satish Balachandra Gummani4, Anil Kumar PR 5, Venkategowda6:1, 2, 3, 4 Bachelor of Engineering in Mechanical engineering, Sapthagiri College of Engineering, Bangalore, Karnataka, India 5,6Assistant Professor, Sapthagiri College of Engineering, Bangalore, Karnataka, India

5. "Automatic Solar Grass Cutter". IJSTE International Journal of Science Technology \& Engineering | Volume 3 | Issue 12 | June 2017

6. "Solar Powered Autonomous Grass Cutting Robot" Professor Rohini P. Onkare1, Pradnyadevi Jagannath Pawar2, Ketaki Kiran Hulgeri3,Sanket Dasharath Gurav4 Asst. Professor, Department of E\&TC, P.V.P.I.T. College of Engineering, Budhgaon, Sangli, Maharashtra, India1 B. E Student, Department of E\&TC, P.V.P.I.T. Budhgaon, Sangli, Maharashtra, India2,3,4. 
